\title{
The identity of the female nurse: a reflection from the perspective of Dubar
}

\author{
Identidade da enfermeira: uma reflexão iluminada pela perspetiva de Dubar \\ Identidad de la enfermera: una reflexión desde la perspectiva de Dubar \\ Marinagela Aparecida Gonçalves Figueiredo* (D); Maria Angélica de Almeida Peres** (DD
}

\begin{abstract}
Background: Studies on professional identity constitute a challenge for research and instigates many considerations. Objective: To reflect on the process of construction of the professional identity of the female nurse according to Florence Nightingale, a precursor of modern nursing in the world.

Key topics under analysis: Theoretical reflection which focuses on two seminal works written by Florence Nightingale: "Notes on Hospitals" (1859), and "Notes on Nursing: what it is and what it is not" (1860), based on the concepts of Claude Dubar about professional identity.

Conclusion: The studies pointed out that the professional identity of the nightingalean nurse was shaped in the hospital, stemming from the knowledge and practice of the principles of care and administration, oriented by discipline, defined by Nightingale. They showed that, by implementing her education model, Nightingale caused a detachment from the identity legitimized by religious orders of that period, which may have contributed to the (re/ de)construction of the professional identity of female nurses.
\end{abstract}

Keywords: history of nursing; social construction of identity; education in nursing; nursing care

\section{Resumo}

Enquadramento: Os estudos sobre a identidade profissional configuram-se como um desafio de investigação e instigam muitas reflexôes.

Objetivo: Refletir sobre o processo de formação da identidade profissional da enfermeira segundo Florence Nightingale, precursora da enfermagem moderna no mundo.

Principais tópicos em análise: Reflexão teórica que se debruça sobre duas obras seminais escritas por Florence Nightingale: "Notes on Hospitals" (1859), e "Notes on Nursing: what it is, and what it is not" (1860), ancorada nos conceitos de Claude Dubar sobre a identidade profissional. Conclusáo: Os estudos apontaram que a identidade profissional da enfermeira nightingaleana se constituiu no espaço hospitalar, a partir do conhecimento e da prática dos princípios de cuidados e de administração, mediados pela disciplina, definidos por Nightingale. Evidenciaram que Nightingale, ao implantar o seu modelo de ensino, provocou uma rutura da identidade legitimada pelas ordens religiosas da época, o que pode ter contribuído para a (re/de)construção da identidade profissional das enfermeiras.

Palavras-chave: história da enfermagem; construçáo social da identidade; educação em enfermagem; cuidado de enfermagem

*Ph.D., RN, University Hospital of the Federal University of Juiz de Fora/MG/Brazil, 36000-300, Minas Gerais, Brazil [mary.hujf@gmail.com]. (1) http://orcid.org/00000003-1382-7819. Contribution to the article: bibliographical research; data collection and analysis, and discussion; writing of the article. Address for correspondence: Rua Dr. Antônio Vieira Penna, nº 426-202, São Mateus, 36000-300, Minas Gerais, Brazil. **Ph.D., RN, Nursing School Anna Nery, Federal University of Rio de Janeiro, 20211-110, Rio de Janeiro, Brazil [angelica.ufrj@uol.com.br]. (1) http://orcid.org/0000-0002-64303540. Contribution to the article: guidance in selection of bibliographical sources, data analysis, discussion; writing of the article.

Revista de Enfermagem Referência

\section{Resumen}

Marco contextual: Los estudios sobre la identidad profesional se configuran como un desafío de investigación y provocan muchas reflexiones.

Objetivo: Reflexionar sobre el proceso de formación de la identidad profesional de la enfermera según Florence Nightingale, precursora de la enfermería moderna en el mundo.

Principales temas en análisis: Reflexión teórica en torno a dos obras muy importantes escritas por Florence Nightingale: "Notes on Hospitals" (1859) y "Notes on Nursing: what it is, and what it is not" (1860), basada en los conceptos de Claude Dubar sobre la identidad profesional.

Conclusión: Los estudios apuntaron a que la identidad profesional de la enfermera nightingaleana se constituyó en el espacio hospitalario, a partir del conocimiento y de la práctica de los principios de los cuidados y de la administración, mediados por la disciplina, definidos por Nightingale. Se observó que Nightingale, al implantar su modelo de enseńanza, provocó una ruptura de la identidad legitimada por las órdenes religiosas de la época, lo que puede haber contribuido a la (re/de)construcción de la identidad profesional de las enfermeras.

Palabras clave: historia de la enfermería; construcción social de la identidad; educación en enfermería; atención de enfermería 


\section{Introduction}

The studies on professional identity become "an exercise of self-knowledge by nurses with a consequent explanation of their identity and their profession's identity" (Padilha, 2006, p. 535). They reaffirm the role of history "in the ongoing development of identity - the identity of individuals, of groups, of nations or generations" (Nelson, 2009, p. 782) and lead to concluding that "history reflects and constitutes identity" (Nelson \& Wall, 2010, p. 01). For Dubar (2012), identities are built during the socialization processes in work and education, within the institutions.

This paper is a theoretical reflection on the formation of the professional identity of the nurse in modern nursing, in two seminal works written by Nightingale: "Notes on Hospitals" (Nightingale, 1859), and "Notes on Nursing: what it is, and what it is not" (Nightingale, $1860)$. Both were published in the author's native language (English) and purchased in the bookstore of Florence Nightingale Museum, in London, England. This reflection is based on Claude Dubar's theoretical framework. Florence Nightingale, "a compelling figure in the development of nursing, [its] identity, public standing, and position within the health care professions" (Nelson \& Rafferty, 2010, p. 06), a figure internationally acclaimed as the precursor of modern nursing, the historical period the profession currently lives in.

The first work submits the report on the health conditions of the Renkioi Hospital (located in the current town of Istanbul), where the author worked during the Crimean War (1854-1856), and a detailed description of how hospitals should be built and operate to care for the sick. The second work discusses the basic principles of nursing care provided to the sick and in a hospital environment. It is written as a guidebook aiming to be a training tool for nurses. It presents a body of specific knowledge of which differs from medical knowledge and details the skills that female nurses need to develop. The author explains the skills throughout the book, mainly in the chapters "Petty Management," "Chattering Hopes and Advices," and "Observation of the sick." The contribution of Nightingale is a historic milestone in what concerns the profes- sionalization of nursing (Lopes, 2012, p. 0506). According to the theoretical design of this study, the identity is the result, "both stable and provisional, individual and collective, subjective and objective, biographical and structural, from the various processes of socialization which, together, build individuals and define institutions" (Dubar, 2005, p. 136). Each generation builds the identity, based on categories and positions inherited from the previous generation, but also using identity strategies of the institutions where the individuals take action (Dubar, 1997, p. 118). For this purpose, individuals need identity references recognized by others in their practice. The skills, tasks, characteristics, competencies, and abilities of individuals form professional identity, which in nursing was shaped by the determinations surrounding it: the knowledge of nursing - knowledge, art, and ethics; its history - its practice, their attributes, power relations and the gender issue; and the formation of its identity consolidated in the hospital environment.

Despite elevating worldwide nursing to the status of profession, the transformations occurring over the years in the health and education fields require yet further studies about their origins, especially regarding their historical heritages, hence this study, to contribute to critical thinking about the history, the scientificity, the professionalization, and the formation of the identity of the female nurse. The objective of this study was to reflect on the process of formation of the professional identity of the nightingalean nurse, based on the concepts of Claude Dubar.

\section{Development}

After the translation of the works by Nightingale, their readings allowed reflecting on the aspects relating to the professional identity of the female nurse, which have contributed to the construction of this identity based on the professional and social relations and the hospital context, over time, described by the author. These aspects, presented in Figure 1, enabled a better visualization and application of Dubar's concepts, which are the theoretical framework of this study. 
1 Hospital - care and training locus: [goal] to restore patients' health with the practice of care principles.

Essential conditions for health [environment precautions]: 1. Fresh air. 2. Light. 3. Ample space. 4. Subdivision of the sick in separate pavilions.

2 Knowledge: [through] experience and daily observation of the sick.

Female nurse: [responsible for] constant care and monitoring.

Practical lesson [of nurses]: observation of symptoms and patient improvement.

3 Duties of nurses: administration of medication and diets, poultice production, leech application, simples dressing, management of wing's ventilation and heating, space and patients' cleaning,

To provide the best conditions to the patient for nature to do its work.

4 Discipline: to accompany the surgeon in his visitations.

Discipline essential elements: 1 Economy of assistance; 2. Easy supervision. 3. Convenience regarding the number of patients in the same infirmary; 4 . Efficiency regarding control of nurses in the wings [of the Hospital].

Figure 1. Aspects related to the nurse's professional identity.

Source: Adapted from Nightingale, F. (1859). Notes on hospitals. London: John W. Parker and

Son, West Strand, (p. 108).

Nightingale, F. (1860). Notes on nursing: what it is, and what it is not. New York: Dover

Publications, (p. 140).

In the $19^{\text {th }}$ century, several changes occurred in all social fields, including in health, leading to the advancement of medicine and favoring the reorganization of hospitals. Besides being a space of healing, the hospital incorporates the technical-scientific development, becoming a place of training not only of future doctors but also other professionals who were in this same space. Nightingale (1860) conceived the creation of the Nightingale Training School for Nurses at Saint Thomas Hospital, considering the hospital as an environment where nurses were prepared for nursing care. Modern nursing evolved in this scenario. Nightingale was a mythical figure in her time, the Lady with the Lamp, acclaimed as the founder of the modern nursing profession, who envisioned a broader approach of health, which considered disease a natural process, so care and treatments should be simple, safe, and focused on environment conditions (McDonald, 2010). Nightingale knew extensively about hospital organization and care for the sick, a skill developed along her journeys to know and learning nursing care, in addition to her voluntary work at the Renkioi Hospital and superintendent position in London hospitals. This experience motivated her to write the selected works. Besides her recognition as the first theorist in the nursing area, the environmentalist theory, discussed in her second work, provided a "profession explanatory basis" (Carvalho, 2009, p. 641). Concerning the hospital as the locus of professional identity formation, Dubar (2005, p. XXI) states that:

All identities are designations relating to a historical era and a time of social context. Thus, all identities are social and linguistic constructions accompanied to a greater or lesser degree by rationalizations and reinterpretations that, sometimes, make them come across as timeless essences.

Identities are shaped within the institutions as a result of successive socializations that occur to the individuals in their working or educative process (Dubar, 2012).

Nightingale is regarded as a social reformer due to her vision of a global system of health care. Before the creation of the training school, Nightingale acted in the reform of London hospitals. Based on mathematical studies, she proved the relationship between the decrease 
in mortality rates and the care provided at the Renkioi Hospital. She, then, became the first woman to publish a statistical work and to be accepted as a member of the Royal Statistical Society and an honorary member of the American Statistical Association (McDonald, 2010). Lopes and Santos (2010, p. 185) report that in 1885 a group of London supporters of Nightingale raised funds so Florence could "carry out civil hospital reforms and establish an Institute for Nurse training". Thus, in 1860, in a teaching system was implemented in London, idealized by Nightingale, whose purpose was the professionalization of nursing. Religious people or any other devotee of the care for the sick had oriented nursing until then, maintaining it in its pre-professional phase (Padilha, Nelson, \& Borestein, 2011). In this system, Nightingale defined the essential points for the functioning of the school: a nurse director; systematized teaching; selection of candidates from the physical, moral, intellectual, and professional competence point of view; close association of training schools with hospitals, keeping its financial and administrative independence; residence available for students during the training period, near the hospital. For the training of nurses, Nightingale aimed at the acquisition of skills and behaviors, personal and professional attributes as a way of improving the social status, and recognition as competent individuals; to achieve this goal, she defined the type of clothing, relations, morality, and ethics as requirements for the selection of candidates. For Carvalho (2013), the role of nurses, according to Nightingale's propositions, "composes the peculiar art of nursing care and the specific professional identity"; "the professional identity is defined by the nightingalean propositions, from 1860 onwards, in the masterly conception of Notes on Nursing - What it is, and what it is not" p. 27). The creation of the school founded by Florence Nightingale led to the collapse of empirical practice, exercised by lay people, aiming at the emergence of a systematic and rational practice based on scientific knowledge (Teodósio, 2014). Another consequence could have been the conception of a new professional identity as a result of the consolidation of nursing as a profession, based on the connection of its knowledge with ideology, taking on the meaning of abnegation, obedience, dedication, which characterized the nursing profession until today. For Teodósio (2014, p. 23), the book "Notes on Nursing: what it is and what it is not" (1860) confirms this approach, as Nightingale emphasizes the vocation, the religiosity, and the devotion as the profile of nurses. Goodrick and Reay (2010) show that the speech in nursing books is a communication vehicle seeking to legitimize professional identities.

On the duties of nurses, Nightingale described the attributes inherent to the practice of the female nurse: true vocation and love for work; duty and conscience; knowledge and experience; daily observation and constant monitoring of patients; formal and systematic preparation of nurses.

The building process of the female nurse's professional identity results from her knowledge, her history, her presence in the various political bodies as well as the relations established with other professionals in the field and with people to whom she provides care. (Queirós, 2015, p. 49)

For Dubar (2005, p. 328), "the * professional knowledge* that requires articulations between practical and technical knowledge is the essence of the identity structured by the profession". The "professional attributes" idealized by Nightingale, based on the principles of care, administration, discipline, and nurse training in a hospital environment, composed the professional identity of the female nurse (Carvalho, 2009, p. 27). Socialization, the foundation of professional identity, occurs using incorporating the way of thinking and acting as a group. While socializing, individuals acquire group values and rules which will become the guiding compass for their attitudes, practices, and behaviors (Dubar, 2005).

Concerning the discipline, Nightingale understood the importance of rules during training and experiences lived in London hospitals and, mainly, in Renkioi Hospital, when she encountered several hindrances for her administration. In the hospital, the lack of resources, hygiene conditions, the resistance of the medical corps, a large number of war casualties, and the unpreparedness of female volunteers who followed her, challenged Nightingale to print a discipline that affected nursing work and its care. Based on her experiences, when returning to London, she 
created an educative system for nurses focused on training, vocation, and discipline (Lopes \& Santos, 2010). In "Notes on Hospital" by Florence Nightingale (1858), the appropriation of rules and conducts amounted to desired professional behaviors, which should be practiced in the hospital, as a part of the working world reality at that time, meaning the professional identity is achieved in and through work. While building identity, multiple positive or negative identifications occur in the relational system of subjects, which are achieved "through the consistency of a language, that is, through the structuring of signs and symbols" (Dubar, 1997, p. 32), as stated in "Notes on Nursing: what it is and what it is not" (1860).

The two works chosen for this study allowed reflecting on the construction of the female nurse's professional identity within the context of her practice and the nursing knowledge/ power of that period.

The theoretical reflection on the construction of the female nurse's identity based on Nightingale's works allowed thinking of another way to contextualize nursing as a profession, taking into account the fragments which shaped its history. The studied works present the elements that composed the field of nursing education all over the world and the aspects which validated its knowledge on the environment, the care, the practice, and the professional identity. Thus, this study contributes to critical thinking about the scientificity of the profession and brings to light the ideas of Nightingale that allowed the evolution of nursing as a profession. Reflections on the profession's past focus on its history as crucial to understanding the present and the future. Reflecting on the history of nursing is a starting point to understanding the nuances of nursing development, and not merely a reference of historiography or of books already written, thereby orienting professionals, teachers, and students towards its importance, helping to reduce the shortcomings in this field of knowledge, connecting past and present, for the shaping of the future.

\section{Conclusion}

Studying the two works by Nightingale was relevant, as they present the foundations for the creation and development of an education system so important it catapulted the nursing profession to another historical phase.

The proposed reflection contributes to critical thinking about the construction of the modern nurse's professional identity by Nightingale and raises new considerations on this identity throughout the evolutional process of the profession until the present day.

This study points out several pieces of evidence that Nightingale contributed to the construction of the female nurse's professional identity, through the elaboration of health reports, proposals and projects for hospitals' construction, for their functioning, and the principles of care for the sick and with the environment. This statement is based on Dubar's concepts presented and discussed in this paper.

The nightingalean model, disseminated worldwide from the 19th century on, created the approach of how a health-restoring hospital, suitable to nursing care, should be, and what nursing is and what it is not, and what defines the nightingalean nurse.

There is evidence that, by creating and deploying the education model and her concepts, Nightingale caused a detachment from the identity legitimized by religious orders, which may have contributed to the (re/de)construction of the female nurses' professional identity.

It is necessary to conduct new studies in countries which implemented the nightingalean model, aimed at the scientific comparison of conceptions in the field of nursing history. The construction of professional identity involves multiple factors, arising from the nursing history, related to the construction of knowledge and professionalization.

\section{References}

Carvalho, V. (2013). Sobre a identidade profissional na enfermagem: Reconsiderações pontuais em visão filosófica. Revista Brasileira de Enfermagem, 66(esp), 24-32. doi:10.1590/S0034-71672013000700003

Carvalho, V. (2009). Da enfermagem hospitalar: Um ponto de vista. Escola Anna Nery, 13(3), 640-644. doi:10.1590/S1414-81452009000300026

Dubar, C. (1997). A socialização: Construção das iden- 
tidades sociais e profissionais. Porto, Portugal: Porto Editora.

Dubar, C. (2005). A socialização: Construção das identidades sociais e profissionais (3 ed.). São Paulo, Brasil: Martins Fontes.

Dubar, C. (2012). A construção de si pela atividade de trabalho: A socialização profissional. Cadernos de Pesquisa, 42(146), 351-367. doi:10.1590/S010015742012000200003

Goodrick, E., \& Reay, T. (2010). Florence Nightingale endures: Legitimizing a new professional role identity. Journal of Management Studies, 47(1). doi:10.1111/ j.1467-6486.2009.00860.x

Lopes, M. (2012). Florence Nightingale: Algumas reflexóes. In Enfermagem: De Nightingale aos dias de hoje 100 anos (pp. 9-18). Coimbra, Portugal: Unidade de Investigação em Ciencias da Saúde/ Escola Superior de Enfermagem de Coimbra. Retrieved from http:// www.index-f.com/referencia/2010pdf/32-181.pdf

Lopes, 1., \& Santos, S. (2010). Florence Nightingale: Apontamentos sobre a fundadora da enfermagem moderna. Revista de Enfermagem Referência, 3(2),181189. Retrieved from http://www.index-f.com/referencia/2010pdf/32-181.pdf

McDonald, L. (2010). Florence Nightingale a hundred years on: Who she was and what she was not. Women's History Review, 19(5), 721-740. doi:10.1080/0961 2025.2010.509934

Nightingale, F. (1859). Notes on hospitals ( $3^{\mathrm{a}} \mathrm{ed}$.). London, England: Harvard College Library.

Nightingale, F. (1860). Notes on nursing: What it is, and what it is not. New York, NY: Dover Publications.

Nelson, S. (2009). Historical amnesia and its consequences: The need to build histories of practice. Texto Contexto Enfermagem, 18(4), 781-787. doi:10.1590/ S0104-07072009000400021

Nelson, S., \& Rafferty, A. M. (2010). Notes on Nightingale: The influence and legacy of a nursing icon. New York, NY: Cornell University Press. Retrieved from https://digitalcommons.ilr.cornell.edu/cgi/viewcontent. cgi? article $=1060 \&$ context $=$ books

Nelson, S., \& Wall, B. (2010). Beyond the received narrative: Finding the voice for a history of all nurses. Nursing Inquiry, 17(2), 93-94. doi:10.1111/j. 1440-1800.2010.00491.x

Padilha, M. I. (2006). História da enfermagem: Ensino, pesquisa e interdisciplinaridade. Escola Anna Nery, 10(3), 532-538. doi:10.1590/S141481452006000300024

Padilha, M. I., Nelson, S., \& Borestein, M. S. (2011). As biografias como um dos caminhos na construção da identidade do profissional da enfermagem. História, Ciências, Saúde, 18(1), 241-252. doi10.1590/S010459702011000500013

Queirós, P. J. (2015). Identidade profissional, história e enfermagem. Revista Investigação em Enfermagem, 45-54. Retrieved from https://www.researchgate.net/ publication/286869862

Teodósio, S. S. (2014). Formação e processos identitários de enfermeiro no Rio Grand do Norte: Memória de egressos (anos de 1970). Retrieved from https://repositorio. ufsc.br/xmlui/handle/123456789/132943 